Diversity and Distrust 



\title{
Diversity and Distrust
}

\author{
CIVIC EDUCATION IN A \\ MULTICULTURAL DEMOCRACY
}

STEPHEN MACEDO

HARVARD UNIVERSITY PRESS

Cambridge, Massachusetts, and London, England 
Copyright $\bigcirc 2000$ by the President and Fellows of Harvard College

All rights reserved

Printed in the United States of America

First Harvard University Press paperback edition, 2003

Sccond printing, 2003

Library of Congress Cataloging-in-Publication Data

Macedo, Stephen, 1957

Diversity and distrust: civic education in a multicultural democracy / Stephen Macedo. p. $\mathrm{cm}$.

Includes bibliographical references and index.

ISPN 0-674-21311-4 (cloth)

ISPN 0-674-01123-6 (papcr)

1. Public schools-United States. 2. Moral education-United States. 3. CitizenshipStudy and teaching-United States. 4. Liberalism-United States. 5. MulticulturalismUnited States. I. Title.

I.A217.2.M33 2000

$371.01 / 0973-\mathrm{dc} 21$

$99-41461$ 
For David 
